\title{
Simulation study of the photovoltaic panel under different operation conditions
}

\author{
Mohammed Alktranee ${ }^{1}$, Péter Bencs ${ }^{1}$ \\ ${ }^{1}$ Department of Fluid and Heat Engineering, Faculty of Mechanical Engineering and Informatics, University of Miskolc, Miskolc, Hungary
}

\section{ABSTRACT}

An increase in the temperature of the photovoltaic (PV) cells is a significant issue in most PV panels application. About $15-20 \%$ of solar radiation is converted to electricity by PV panels, and the rest converts to heat that affects their efficiency. This paper studies the effects of temperature distribution on the PV panel at different solar radiation values, temperatures under different operation conditions in January and July. A 3D model of the PV panel was simulated with ANSYS software, depending on the various values of temperatures and solar radiation values obtained using mathematic equations. The simulation results indicate that PV panel temperature lowered with solar radiation values lower in January, and the temperature was homogeneous on the PV panel surface. An increase in the solar radiation value and temperature in July led causes heating of the PV panel with observed a convergence of the maximum and average temperature of the panel. Thus, the PV panel temperature increase is directly proportional to the solar radiation increase that causes lower performance. Cooling the PV panel by passive or active cooling represents the optimum option to enhance their performance and avoid increasing the PV cells' temperature at temperature increase.

\section{Section: RESEARCH PAPER}

Keywords: Photovoltaic; solar radiation; simulation; temperature

Citation: Mohammed Alktranee, Péter Bencs, Simulation study of the photovoltaic panel under different operation conditions, Acta IMEKO, vol. 10, no. 4, article 12, December 2021, identifier: IMEKO-ACTA-10 (2021)-04-12

Section Editor: Francesco Lamonaca, University of Calabria, Italy

Received March 28, 2021; In final form September 25, 2021; Published December 2021

Copyright: This is an open-access article distributed under the terms of the Creative Commons Attribution 3.0 License, which permits unrestricted use, distribution, and reproduction in any medium, provided the original author and source are credited.

Corresponding author: Mohammed Alktranee, e-mail: mohammed84alktranee@gmail.com

\section{INTRODUCTION}

Solar energy is the essential branch of renewable energy is used in different applications as an alternative source of conventional systems such as solar electrical generation, solar cooling systems, solar heating, etc. [1]. The photovoltaic (PV) panels are one solar energy technology used for electrical generation by PV cells made of semiconductor materials. The PV cells convert the sunlight (photons energy) into electrical energy, where about $15 \%-20 \%$ of the sunlight converts to electricity, and the rest converts to heat which influences their performance [2]. Different factors influence the PV panel performance; some are related to the balance of system (subsystems) failure, such as PV inverter [3]. Others are regarding operation conditions, cell cracking problems due to wind or snow pressure, vibrations, and the dust that collects on the PV module, which causes a failure along its operating lifetime during a short lifetime [4]. The PV panels efficiency is significantly affected by the increase in the PV cells temperature that causes cell degradation and shorting of life expected of PV module with dropped output power [5].
Several studies revealed the performance of the PV panel is affected by the operation temperature. Increasing the PV cells temperature higher than $25^{\circ} \mathrm{C}$ has negative effects on the PV cells yield, where decreases the open-circuit voltage and then the electrical output of the PV panel [6]-[8]. The PV cells performance and productivity mainly depend on the solar radiation values and ambient temperature.

Therefore, at an average temperature of $25^{\circ} \mathrm{C}$ and solar radiation of $1000 \mathrm{~W} / \mathrm{m}^{2}$, the $\mathrm{PV}$ cells give a maximum yield generate as a reference power produced by the PV cells [9]. Stander test condition (STC) is a concept defined as the performance of $\mathrm{PV}$ cells within a temperature of $25^{\circ} \mathrm{C}$ and solar radiation of $1000 \mathrm{~W} / \mathrm{m}^{2}$. Increasing the temperature of the PV panel temperature one degree higher than $25^{\circ} \mathrm{C}$ leads to reducing the PV cells efficiency to $0.45 \%$ [10]. Therefore, various PV models have been developed to predict the PV modules power output under different operation conditions [11]. A thermal model was developed to simulate PV panels thermal and electrical performance under different operation conditions with and without cooling. The developed model was sequentially linked with electrical and radiation models to evaluate the PV 


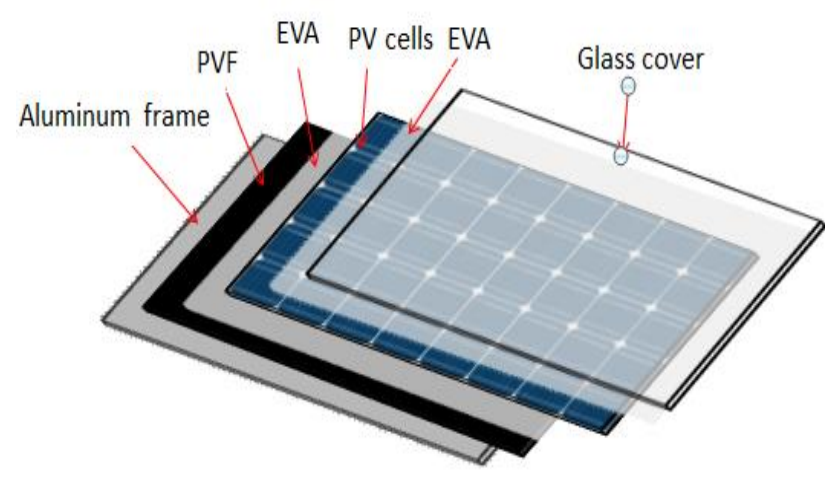

Figure 1. The layers of the PV panels.

panels performance. The simulation results show lower PV panel performance with absorbed solar radiation of $800 \mathrm{~W} / \mathrm{m}^{2}$ and ambient temperature $0{ }^{\circ} \mathrm{C}-50^{\circ} \mathrm{C}$ without cooling.

Meanwhile, use cooling has a slight increase of the PV panels at ambient temperature $25^{\circ} \mathrm{C}$ and absorbed radiation from $200 \mathrm{~W} / \mathrm{m}^{2}$ to $1000 \mathrm{~W} / \mathrm{m}^{2}$ [11]. The ambient temperature and solar radiation are important parameters that influence the PV cells' conversion efficiency and power produced [12]. Another 3D model was simulated by ANSYS software to evaluate temperature distribution on the PV panel at different climate conditions and thus analysing the PV panels thermal behaviour under operating conditions. The results indicate an increase in the PV panel temperature is associated with increased solar radiation intensity and ambient temperature [13]. Another simulation was conducted of the PV panel at a constant temperature with various solar radiation values, vice versa to predict the PV model performance and compare it with the PV panel performance under STC. The simulation revealed a reduction of solar radiation values even with constant temperature effects on the voltage and current of the PV panel. On the other hand, the PV panel performance degraded at high temperatures even with different solar radiation values. Thus, lowering the temperature of the PV panel contributes to an increase in output power [14].

The present work aims to calculate temperature distribution on the PV panel at different solar radiation values and ambient temperature then determine the optimum operation condition extent of the PV panel. The simulation depended on the layers properties of the PV panel, values of solar radiation, temperature, convective heat transfer coefficient of the model to evaluate temperature distribution and identify the appropriate extent of operating conditions of the PV panel. The second section will discuss the characteristics of the PV panel and the mathematic equation used to predict the solar radiation values and the important results obtained. The third section discussed the simulation results and compared it with other studies [15], [16] that simulated under similar conditions to investigate the effect

Table 1. The layers properties of the PV panel [17].

\begin{tabular}{cccc}
\hline Material (Layer) & $\begin{array}{c}\rho \\
\mathbf{k g} / \mathbf{m}^{\mathbf{3}}\end{array}$ & $\begin{array}{c}\boldsymbol{K} \\
\mathbf{W} /\left(\mathbf{m}^{\mathbf{2}} \cdot \mathbf{K}\right)\end{array}$ & $\begin{array}{c}\boldsymbol{C} \mathbf{p} \\
\mathbf{J} /(\mathbf{k g} \cdot \mathbf{K})\end{array}$ \\
\hline Glass & 3000 & 1.8 & 500 \\
EVA & 960 & 0.35 & 2090 \\
PV & 2330 & 148 & 677 \\
PVF & 1200 & 0.2 & 1250 \\
Aluminium Frame & 2707 & 204 & 996 \\
\hline
\end{tabular}

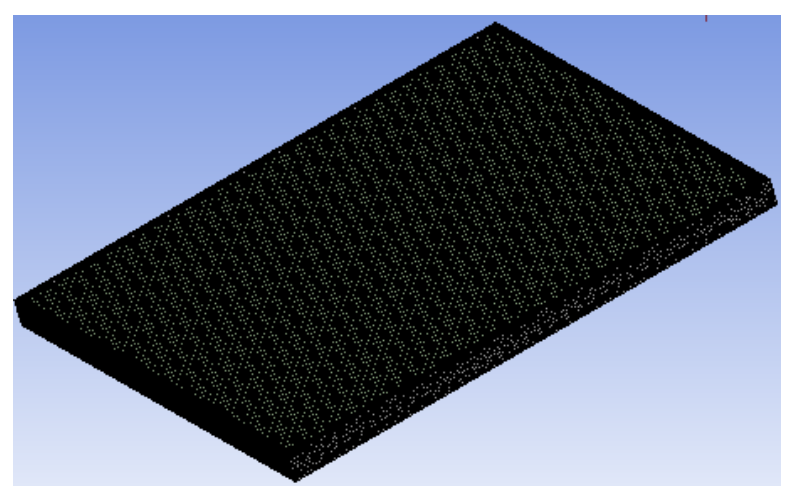

Figure 2. Depict the PV panel meshing.

of ambient temperature and solar radiation on the PV panel performance.

\section{METHODOLOGY}

The PV panel used type AS-6P30 Polycrystalline, consisting of glass covering, PV cells with two layers of Ethylene Vinyl Acetate (EVA), aluminium frame, and Tedlar (PVF) layer, as shown in Figure 1 below. Table 1 below shows the material properties of the PV components inserted in the ANSYS software engineering data. The PV panel datasheet has adopted a reference for comparing the simulation results and the PV panel values under STC.

\subsection{Geometry simulation}

According to the manufacturer datasheet, the PV model's geometry is built by SolidWorks software with $1640 \times 992 \times 35 \mathrm{~mm}^{3}$ model dimensions. The materials are defined by the ANSYS library data of all the PV panel layers, as shown in Figure 1. The PV model has been imported to the Ansys software to analyse the PV panels temperature distribution inserted in the software as variable values depending on the different values of beam solar radiation obtained using mathematical equations below.

Thus, according to STC, three solar radiation values have been used two of them according to January and July with an estimation of clear-sky radiation and the third solar radiation value under STC. The heat flux changes with time, which causes a change in the temperature that influences the PV panels performance. The temperature was fixed at $4{ }^{\circ} \mathrm{C}$ in January, 35 ${ }^{\circ} \mathrm{C}$ in July, and $25{ }^{\circ} \mathrm{C}$ in STC. The value of the convective heat transfer coefficient on the panel is 14.8 , given in $\mathrm{W} /\left(\mathrm{m}^{2} \mathrm{~K}\right)$ and calculated using equation (1) [18]

$$
h=5.7+3.8 V_{m},
$$

where $V_{m}$ is the wind speed value that adopted 2.4 , given in $\mathrm{m} / \mathrm{s}$, according to Miskolc city [19]. The mesh element size of the PV model mesh using ANSYS simulation software was $0.002 \mathrm{~m}$, and the number of meshes elements was 278964 with high smoothing, as shown in Figure 2 above, the time simulated was $43.1 \mathrm{~min}$ in all initial conditions, Figure 3 show the simulation steps of the PV panel for of January, July and for STC values.

\subsection{Governing mathematical equations}

The mathematical equations were used to predict and estimate direct radiations transmittance (beam radiation) for Miskolc city when a clear atmosphere on 7 January at solar time 11:30 AM and 13 July with solar time 12:30 PM. To achieve that, it needs to find some parameters that help achieve that such angular 


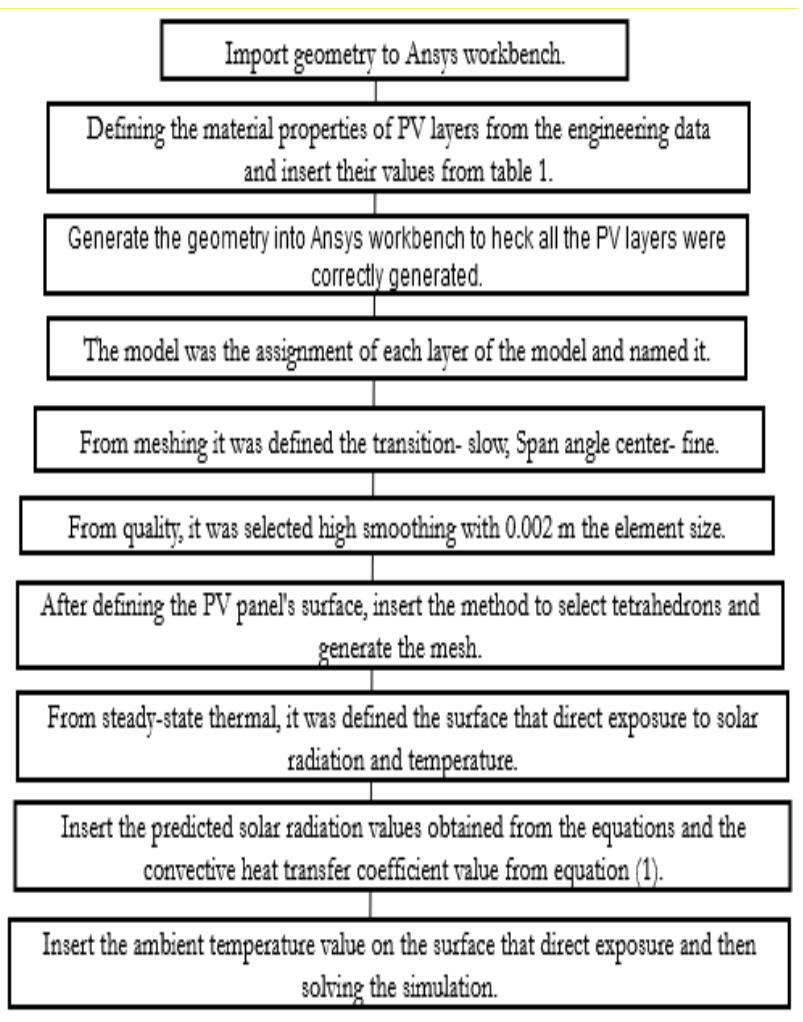

Figure 3. Simulation steps of the PV panel.

position of the sun (solar declination $\delta$ ) represents the angle between the line from the centre of the sun to the earth centre equator. The solar declination value is changeable because of the rotating the earth around the sun and the tilt of the earth on its axis of rotation found by using Cooper's equation [20]

$$
\delta=23.45^{\circ} \sin \left(360 \frac{284+n}{365}\right),
$$

where $n$ is the day of the year of that selected date $(n=7$ for 7 January and $n=194$ for 13 July).

The zenith angle is the incidence beam solar radiation angle between the vertical and the line to the sun use with horizontal surfaces and determined by the following equation

$$
\cos \theta_{z}=\cos \phi \cos \delta \cos \omega+\sin \phi \sin \delta,
$$

with latitude $\phi$ between $-90^{\circ} \leq \phi \leq 90^{\circ}$ for Miskolc, Hungary $\phi$ is $48.1^{\circ}, \omega$ is hour angle which is negative at morning and afternoon positive. Solar time depends on the sun's angular motion in the sky, which may not synchronize with local time [21]. The extra-terrestrial radiation incident $G_{\text {on }}$ is the quantity of solar energy received per unit of time at the mean distance between the sun to the earth. On the normal plane, the $G_{\text {on }}$ can calculate by the equation (4)

$$
G_{\mathrm{o}}=G_{\mathrm{sc}}\left(1+0.033 \cos \frac{360 n}{365}\right),
$$

and $G_{\text {sc }}$ is the solar constant.

Calculating the daily and hourly solar radiation received on a horizontal surface is useful under standard conditions. To calculate the beam radiation transmitted from the sun without scattering by clear atmospheres, consider the zenith angle and altitude of the atmosphere for four climate types from equation (5) [21]

$$
\begin{aligned}
& \tau_{b}=a_{0}+a_{1} \mathrm{e}^{-\frac{k}{\cos \theta_{z}}} \\
& a_{0}^{*}=0.4237-0.00821(6-A)^{2}, \\
& a_{1}^{*}=0.5055+0.00595(6.5-A)^{2}, \\
& k^{*}=0.2711+0.01858(2.5-A)^{2},
\end{aligned}
$$

where $a_{0}, a_{1}$ are constant, and $k$ represents the standard atmosphere at $23 \mathrm{~km}$ visibility that can be found by using the equation (6), (7), and (8) A represents the altitude of the observer in kilometres.

Hence, multiply the constant values by correction factors in Table $2, a_{0}^{*} \times r_{o}, a_{1} \times a_{1}^{*}$ and $k \times r_{k}$ could calculate the beam radiation transmitted. Thus, it can determine the beam radiation for any zenith angle or altitude, even $2.5 \mathrm{~km}$. The normal beam radiation in the clear sky can be found by multiplying the value of the beam radiation transmitted during clear atmospheres $\tau_{b}$ by the value of extraterrestrial radiation incident $G_{\text {on }}$. The value results multiply by the zenith angle to obtain solar radiations value on the horizontal of panel $G_{\mathrm{cb}}$ [22].

\section{RESULTS AND DISCUSSION}

The PV panel has been simulated under different solar radiation values estimated by mathematical equations and various temperatures. For January, solar radiation values were $176 \mathrm{~W} / \mathrm{m}^{2}$, for July was $735 \mathrm{~W} / \mathrm{m}^{2}$ and under STC was $1000 \mathrm{~W} / \mathrm{m}^{2}$. January's highest temperature was $4{ }^{\circ} \mathrm{C}$, July highest temperature reaches $35^{\circ} \mathrm{C}$, and the PV panel temperature was under STC $25^{\circ} \mathrm{C}$. The results indicate that temperature distribution on the PV panels surface was high at the top of the PV panel while the aluminium frame's temperature was lower. The dark-blue colour refers to the minimum temperature on the panel, the bright-red colour refers to the maximum temperature on the panel, and other colours represent temperature variations.

In January, when the temperature is low, the beam solar radiation is $176 \mathrm{~W} / \mathrm{m}^{2}$. The temperature distribution on the PV panel is between a maximum temperature of $15.4{ }^{\circ} \mathrm{C}$ and a minimum of $11.9^{\circ} \mathrm{C}$, as shown in Figure 4. Thus, this solar radiation range influences $\mathrm{PV}$ panel performance represented by power output, without leaving any damage or overheating because of lower the PV panel temperature. At applied the July solar radiation $735 \mathrm{~W} / \mathrm{m}^{2}$ when the temperature reaches $35^{\circ} \mathrm{C}$, the simulation shows that the PV panel is exposed to a maximum temperature of $84.6{ }^{\circ} \mathrm{C}$, while the minimum temperature was $68.4^{\circ} \mathrm{C}$ as shown in Figure 5 above. Increase the PV panel temperature by $10^{\circ} \mathrm{C}$ above the STC value causes a decrease in its efficiency. This extent of temperature causes other problems for the PV panel, such as overheating, which leads to burning some cells or reduced voltage, power, and the PV panel's output current; thus, the PV panel becomes inoperative [23].

Table 2. Correction factors for climate types [20].

\begin{tabular}{cccc}
\hline Climate Type & $\boldsymbol{r}_{\boldsymbol{o}}$ & $\boldsymbol{r}_{\mathbf{1}}$ & $\boldsymbol{r}_{\boldsymbol{k}}$ \\
\hline Tropical & 0.95 & 0.85 & 1.02 \\
Mid latitude winter & 1.03 & 1.01 & 1 \\
Subarctic summer & 0.99 & 0.99 & 1.01 \\
Mid latitude summer & 0.97 & 0.99 & 1.02 \\
\hline
\end{tabular}




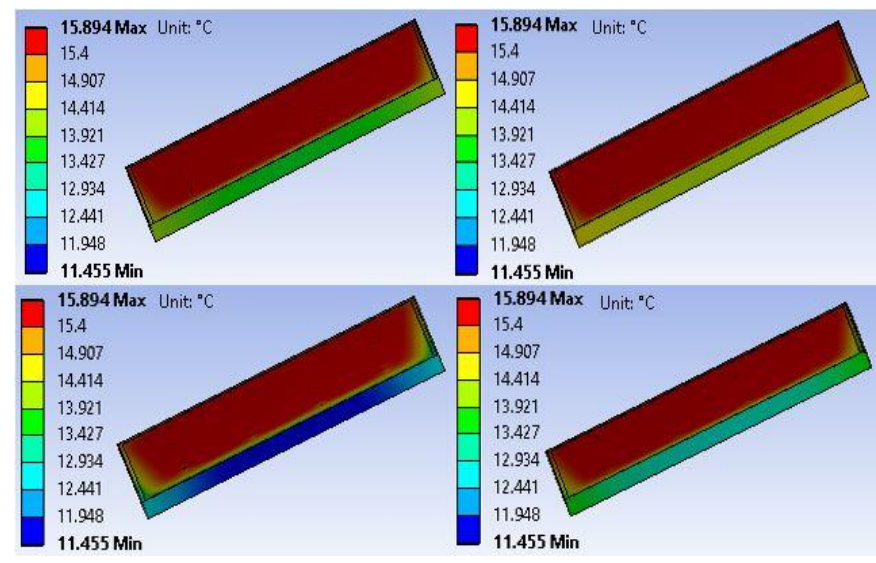

Figure 4. At solar radiation $176 \mathrm{~W} / \mathrm{m}^{2}$ and temperature $4{ }^{\circ} \mathrm{C}$.

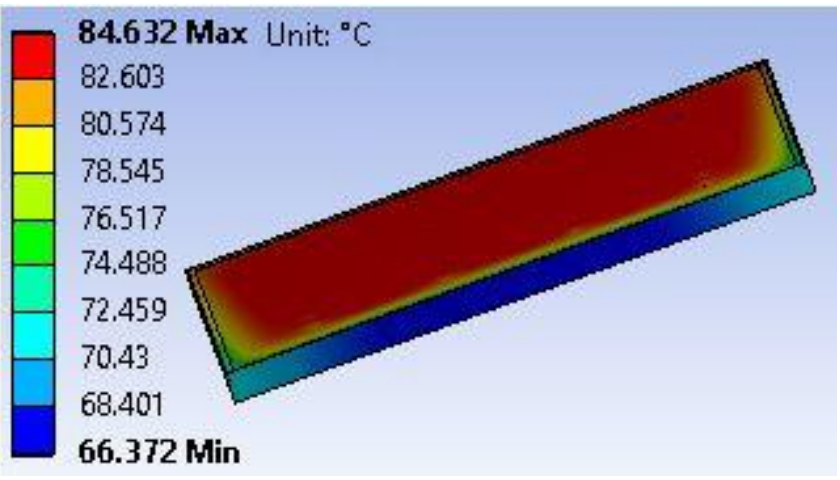

Figure 5 . At solar radiation $734 \mathrm{~W} / \mathrm{m}^{2}$ and temperature $35^{\circ} \mathrm{C}$.

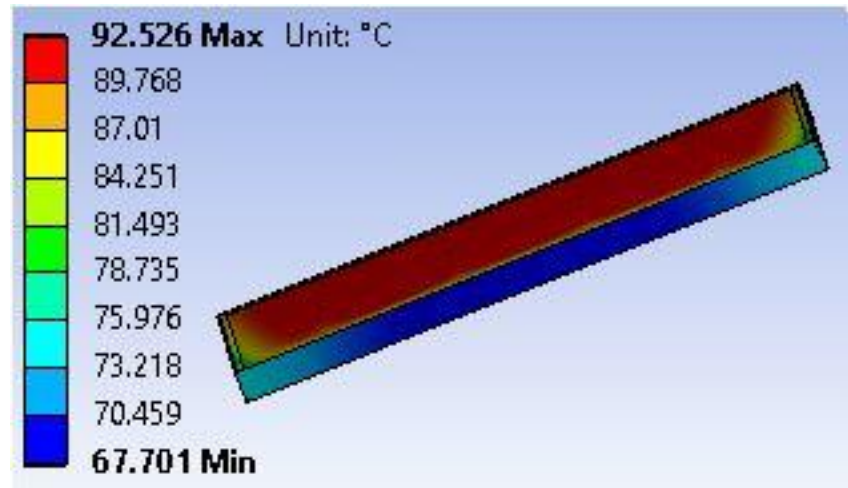

Figure 6. At solar radiation $1000 \mathrm{~W} / \mathrm{m}^{2}$ and temperature $25^{\circ} \mathrm{C}$.

Under STC conditions of the PV panel $1000 \mathrm{~W} / \mathrm{m}^{2}$ and $25^{\circ} \mathrm{C}$, observed rising the PV panel temperature until $92.5^{\circ} \mathrm{C}$, while the lowest temperature was $67.7^{\circ} \mathrm{C}$, as shown in Figure 6 above. Therefore, this temperature range is not suitable for PV panel operation due to the rising of the PV cells temperature and causes the same problems of July values as overheating PV cells or reduced conversion efficiency and production of the PV panel. The temperature increase of the PV panel is directly proportional to increasing solar radiation. Due to the PV layers different properties, these layers temperature is different, as shown in the Figures above; the PV panel temperatures surface is different from the aluminium frame. The maximum and average temperatures on the PV panel are converged somewhat at increasing the solar radiation, as shown in Table 3 above, for July and STC values. The cooling of the PV panel to remove the excessive heat is important to continue its work under high temperatures, even with STC values.
Table 3. Temperatures on the PV panel at different solar radiation.

\begin{tabular}{cccc}
\hline $\begin{array}{c}\text { Solar } \\
\text { radiation } \\
\mathbf{W} / \mathbf{m}^{2}\end{array}$ & $\begin{array}{c}\text { Max } \\
\text { temperature } \\
{ }^{\circ} \mathbf{C}\end{array}$ & $\begin{array}{c}\text { Min } \\
\text { temperature } \\
{ }^{\circ} \mathbf{C}\end{array}$ & $\begin{array}{c}\text { Average } \\
\text { temperature } \\
{ }^{\circ} \mathbf{C}\end{array}$ \\
\hline 176 & 15.8 & 11.4 & 15.2 \\
735 & 84.6 & 66.3 & 82.1 \\
1000 & 92.5 & 67.7 & 89.1 \\
\hline
\end{tabular}

\section{CONCLUSION}

The PV panel was simulated by ANSYS software according to the properties of the material of the PV layers, such as thermal conductivity, densities, and specific heat for each layer. The climatic conditions of Miskolc city have depended on solar radiation, temperatures, and wind speed as a parameter in simulation. The solar radiation values have been estimated depending on the mathematical equations for January and July with an STC standard value. The PV panel showed a variable thermal behaviour with a change in solar radiations value, which became evident by the PV panel's distribution temperatures.

Thus, low solar radiation value and temperature influence the PV panels performance to the extent that it does not cause damage to the PV panel but reduces production. On the other hand, increasing solar radiation causes an increase in the PV panels temperature that causes reduce in power output with damage to the PV panel. A convergence of the maximum and average temperature was observed with increasing the solar radiation that causes the rising of $\mathrm{PV}$ cells temperature that requires cooling of the PV panel to remove the excessive heat.

\section{REFERENCES}

[1] V. V. Tyagi, N. A. A. Rahim, N. A. Rahim, J. Selvaraj, Progress in solar PV technology: research and achievement, Renew Sustain Energy Rev, 20 (2013), pp. 443-61.

DOI: $10.1016 /$ i.rser.2012.09.028

[2] M. C. Browne, B. Norton, S. J. Mccormack, Heat retention of photovoltaic/thermal collector with PCM, Sol Energy, 133 (2016), pp. 533-48.

DOI: 10.1016/j. solener.2016.04.024

[3] Loredana Cristaldi, Mohamed Khalil, Payam Soulatiantork, A root cause analysis and a risk evaluation of $\mathrm{PV}$ balance of systems failures, ACTA IMEKO 6 (2007) 4, pp.113-120.

DOI: $10.21014 /$ acta imeko.v6i4.425

[4] Loredana Cristaldi, Mohamed Khalil, Marco Faifer, Markov process reliability model for photovoltaic module failures, ACTA IMEKO 6 (2017), pp. 121-130.

DOI: $10.21014 /$ acta imeko.v6i4.428

[5] Aarti Kane, Vishal Verma, Bhim Singhc, Optimization of thermoelectric cooling technology for active cooling of a photovoltaic panel, Renewable and Sustainable Energy Reviews 75 (2017), pp.1295-1305.

DOI: $10.1016 /$ j.rser.2016.11.114

[6] Fesharaki VJ, Dehghani M, Fesharaki JJ, The Effect of Temperature on Photovoltaic Cell Efficiency, Proceedings of the 1st International Conference on ETEC, Tehran, Iran, 2011.

[7] Borkar DS, Prayagi SV, Gotmare J, Performance Evaluation of Photovoltaic Solar Panel Using Thermoelectric Cooling, International Journal of Engineering Research 9(2014), pp. 536539.

[8] Fontenault B, Active Forced Convection Photovoltaic/Thermal Panel Efficiency Optimization Analysis, Rensselaer Polytechnic Institute Hartford, 2012.

[9] Skoplaki E, Palyvos JA, On the temperature dependence of photovoltaic module electrical performance: A review of 
efficiency/power correlations, Solar Energy 83(2009), pp. 614 624.

[10] Solar Facts: Photovoltaic Efficiency - Inherent and System. Online [Accessed 8 December 2021]

https://www.solar-facts.com/panels/panel-efficiency.php

[11] G. M. Tina, S. Scrofani, Electrical and thermal model for PV module temperature evaluation, IEEE, 2008.

DOI: $10.1109 /$ MELCON.2008.4618498

[12] Cătălin George Popovici, Sebastian Valeriu Hudișteanu, Theodor Dorin Mateescu, Nelu-Cristian Cherecheș. Efficiency improvement of photovoltaic panels by using air cooled heat sinks, Energy Procedia. 85 (2016) pp. 425 - 432. DOI: $10.1016 /$ j.egypro.2015.12.223

[13] Leow W Z, Irwan Y M, Safwati I, Irwanto M, Amelia A R, Syafiqah Z, Fahmi M I and Rosle N, Simulation study on photovoltaic panel temperature under different solar radiation using a computational fluid dynamic method. Journal of Physics, Conference Series, IOP 1432 (2020).

DOI: $10.1088 / 1742-6596 / 1432 / 1 / 012052$

[14] Mohammed Alktranee and Péter Bencs, Test the mathematical of the photovoltaic model under different conditions by use MatlabSimulink, Journal of Mechanical Engineering Research and Developments Vol 43 (2020), pp. 514-521.

[15] Marek Jaszczur, Qusay Hassan, Janusz Teneta, Ewelina Majewska1, Marcin Zych, An analysis of temperature distribution in solar photovoltaic module under various environmental conditions, MATEC Web of Conferences 240, 04004 (2018). DOI: $10.1051 /$ matecconf/201824004004

[16] N. Pandiarajan and Ranganath Muthu, Mathematical Modeling of
Photovoltaic Module with Simulink, International Conference on Electrical Energy Systems (ICEES 2011) (2011), pp. 3-5. DOI: 10.1109/ICEES.2011.5725339

[17] S. Armstrong, W. G. Hurley, A Thermal Photovoltaic Panels under Varying Atmospheric Conditions, Applied Thermal Engineering 30(2010), pp. 1488-1495.

DOI: $10.1016 /$ i.applthermaleng.2010.03.012

[18] J. Vlachopoulos, D. Strutt, Heat Transfer, In SPE Plastics Technicians Toolbox 2 (2002), pp. 21-33.

[19] Weather and climate, Miskolc, Hungary. Online [Accessed 5 March 2021] https://weather-and-climate.com/average-monthly-RainfallTemperature-Sunshine,Miskolc,Hungary

[20] Cooper, P. I, The Absorption of Solar Radiation in Solar Stills, Solar Energy 3 (1969), pp. 333-346. DOI: $10.1016 / 0038-092 X(69) 90047-4$

[21] John A. Duffie, William A, Beckman, Solar Engineering of Thermal Processes, Fourth Edition. ISBN 978-0-470-87366-3 (2013).

[22] Hottel, H. C, A Simple Model for Estimating the Transmittance of Direct Solar Radiation Through Clear Atmospheres, Solar Energy 2 (1976), pp. 129-134. DOI: $10.1016 / 0038-092 X(76) 90045-1$

[23] Bodnár, I., Iski, P., Koós, D., Skribanek, Á, Examination of electricity production loss of a solar panel in case of different types and concentration of dust, Advances and Trends in Engineering Sciences and Technologies III (2019), pp. 313-318. DOI: $10.1201 / 9780429021596-49$ 